\title{
PENGARUH VARIASI WAKTU PEMERAMAN TELUR ASIN DENGAN PENAMBAHAN ABU SABUT KELAPA TERHADAP KANDUNGAN KADAR KLORIDA, KADAR PROTEIN DAN TINGKAT KESUKAAN KONSUMEN
}

\section{The Effect of Variations Ripened Time The Salted Egg With Addition of Coconut Fiber Ash On The Content of Chloride and Protein, and The Level of Hedonic}

\author{
Emil Salim 1), Husain Syam²), dan Mohammad Wijaya3) \\ ${ }^{1}$ Alumni Program Studi Pendidikan Teknologi Pertanian \\ ${ }^{2}$ dan ${ }^{3}$ Dosen PTP FT UNM \\ emilsalim_xtm@yahoo.com
}

\begin{abstract}
ABSTRAK
Telur asin adalah telur yang diawetkan dengan cara diasinkan. Penelitian ini bertujuan untuk mengetahui pengaruh variasi waktu pemeraman telur asin dengan penambahan abu sabut kelapa terhadap kadar klorida, kadar protein dan tingkat kesukaan. Variabel perlakuan adalah variasi waktu pemeraman 7, 14, dan 21 hari. Penelitian ini menggunakan Rancangan Acak Lengkap (RAL) faktor tunggal. Parameter yang diamati adalah kadar klorida, kadar protein dan tingkat kesukaan. Data hasil penelitian diolah menggunakan teknik analisis sidik ragam ANOVA dengan uji lanjut DMRT (Duncan Multiple Range Test). Hasil penelitian menunjukan kadar klorida dan tingkat kesukaan terbaik terdapat pada perlakuan 21 hari sedangkan untuk kadar klorida terbaik terdapat pada perlakuan 7 hari.

Kata Kunci : Telur, Variasi Waktu, Abu Sabut Kelapa, Telur Asin.
\end{abstract}

\section{ABSTRACT}

Salted eggs are eggs preserved by marinated. This research aims to determine the effect of variations ripened of salted egg with addition of coconut fiber ash on the chloride and protein content, and the level of hedonic. Variable of this research were the variations ripened time of 7, 14 and 21 days. The research design by using a completely randomized design (CRD) single factor. The Parameters of this research were the content of chloride and protein, and the level of hedonic. Data of the research were analyzed by using ANOVA variance analysis techniques to further test DMRT (Duncan Multiple range test). The results of this research showed that the best chloride content and level of hedonic ripened in 21 days treatment, while for the best protein content ripened in 7 days treatment.

Keywords: Egg, Time Variation, Coconut fiber Ash, Salted Egg.

\section{PENDAHULUAN}

Produksi itik di Indonesia mencapai 14 juta ekor merupakan $16 \%$ dari populasi itik yang ada di Asia dan menjadi Negara penghasil telur itik terbesar di dunia. Indonesia juga merupakan satusatunya Negara di dunia yang jumlah produksi telur itiknya lebih besar dari produksi telur ayam (Chaves et al dalam Wahyudi Eka Putra et al, 2014).

Telur itik merupakan bahan pangan yang mengandung protein cukup tinggi dengan susunan asam-asam amino lengkap. Selain itu, telur itik juga mengandung lemak tak jenuh, vitamin, 
dan mineral yang diperlukan tubuh dan sangat mudah dicerna. Rasa yang enak, harga yang relatif murah serta dapat diolah menjadi berbagai macam produk makanan, menyebabkan telur banyak dikonsumsi oleh masyarakat (Wahyudi Eka Putra et al, 2014).

Ketersediaan telur tidak mengenal musim, namun telur juga memiliki kelemahan byaitu mudah mengalami kerusakan seperti telur unggas lainnya baik secara fisik, kimia, maupun oleh mikroba. Kerusakan yang terjadi pada telur akan mempengaruhi kualitas dan daya simpan telur. Maka dari itu, usaha pengawetan perlu dilakukan untuk mempertahankan kualitas telur (Armenia et al, 2014).

Pengawetan telur yang banyak dan sampai sekarang paling dikenal serta paling digemari oleh masyarakat Indonesia adalah telur asin. Tujuan utama dari proses pengasinan telur ini selain membuang rasa amis dan menciptakan rasa yang khas adalah untuk memperpanjang masa simpan telur. Penggunaan kadar garam yang tinggi dalam produk telur asin selain dapat menyebabkan tingkat keasinan meningkat juga berkontribusi secara nyata terhadap prevalensi kejadian hipertensi juga dapat mengakibatkan protein telur mengalami denaturasi. Hal ini disebabkan adanya gangguan atau perubahan pada struktur sekunder dan tersier akibat terjadinya interaksi dengan garam (Safrullah Amir et al. 2014).

Limbah abu sabut kelapa yang banyak ditemukan dimasyarakat yang biasanya kurang dimanfaatkan kembali, selain digunakan sebagai abu gosok. Manfaat lain dari abu sabut kelapa yaitu dapat mengganti mediasekaligus pengganti garam dalam proses pembuatan produk pangan telur asin. Penggunaan abu sabut kelapa yang merupakan limbah pertanian untuk membungkus telur selama pemeraman, tidak perlu penambahan garam, karena didalam abu tersebut mengandung kalium lebih banyak dan garam $25.67 \%$ dengan kandungan klorida 10\%. Hal ini sangat baik untuk diet garam karena menggunakan sedikit garam dalam pembuatan telur asin. Hal-hal tersebut menjadi dasar untuk melakukan penelitian tentang "Pengaruh Variasi Waktu Pemeraman Telur Asin dengan Menggunakan Abu Sabut Kelapa Terhadap Kandungan kadar klorida, kadar Protein dan Tingkat Kesukaan Konsumen".

\section{TUJUAN PENELITIAN}

Tujuan penelitian untuk mengetahui waktu terbaik pembuatan telur asin, dan kandungan kadar klorida, kadar protein serta tingkat kesukaan konsumen terhadap telur asin hasil pengasinan abu sabut kelapa dengan waktu pemeraman yang berbeda.

\section{METODOLOGI PENELITIAN}

Jenis penelitian ini adalah penelitian kuantitatif dengan pendekatan eksperimen, Rancangan percobaan yang digunakan dalam penelitian ini adalah rancangan acak lengkap (RAL) pola faktor tunggal. yang terdiri dari lama pemeraman 7 hari, 14 hari, dan 21 hari, perlakuan diulang sebanyak 3 kali.

\section{Alat dan Bahan penelitian}

Peralatan yang digunakan dalam proses pembuatan telur asin antara lain : timbangan analitik, timbangan duduk, rak telur, baskom, sendok kayu, panci, kompor gas, pisau, kemasan plastic, kertas label, sarung tangan, dan talenan. 
Bahan-bahan yang digunakan dalam pembuatan telur asin antara lain : telur itik sebanyak 120 butir, sabut kelapa $22,5 \mathrm{~kg}$, abu sabut kelapa $4,5 \mathrm{~kg}$, abu gosok $1 \mathrm{~kg}$, garam dapur $1 \mathrm{~kg}$, dan air secukupnya.

\section{Prosedur Penelitian}

\section{a. Pembuatan adonan abu kulit kelapa}

1. Adonan dibuat dengan membakar limbah sabut kelapa kering sehingga menjadi abu .1 kg limbah sabutkelapa kering diperoleh 200 gram abu, 1 butir telur membutuhkan $50 \mathrm{gr}$ abu sabut kelapa. Jadi untuk membungkus 120 butir telur membutuhkan : 90 butir telur bebek $\times 50 \mathrm{gr}$ abu $=4.500 \mathrm{gr}$ abu, Untuk memperoleh $4.500 \mathrm{gr}$ abu dibutuhkan $4,5 \mathrm{~kg}$ limbah abu sabut kelapa, dan sabut kelapa sejumlah (1 kilogram $=200$ gram) $: 4.500: 200=$ $22,5 \mathrm{~kg} . \quad 30$ butir digunakan dalam pembuatan telur asin dengan media abu gosok dan garam.

2. Mencampur abu sabut kelapa dengan air sampai rata sehingga menjadi adonan yang dapat dipulung.

\section{b. Pembuatan telur asin}

Alur pembuatan telur asin dengan tahapan yang meliputi :

1. Pilih telur yang bermutu baik (tidak retak atau busuk).

2. Bersihkan telur dengan mencuci atau dilap dengan air, kemudian keringkan.

3. Amplas seluruh permukaan telur agar pori-porinya terbuka.

4. Buat adonan pengasin dari campuran $1 \mathrm{~kg}$ abu sabut kelapa dan air secukupnya. Sedangkan untuk kontrol digunakan abu gosok dan garam dengan perbandingan 1:1 (1 kg: $1 \mathrm{~kg})$ dan air secukupnya.

5. Tambahkan sedikit demi sedikit air ke dalam adonan kemudian aduk sampai adonan berbentuk pasta.
6. Bungkus telur dengan adonan satu persatu secara merata sekeliling permukaan telur, kira-kira setebal 1-2 $\mathrm{mm}$.

7. Simpan telur dalam ember plastik selama 7, 14 dan 21 hari sedangkan untuk kontrol di simpan selama 7 hari. Usahakan agar telur tidak pecah, simpan di tempat yang bersih dan terbuka.

8. Setelah selesai bersihkan telur dari adonan kemudian direbus selama 30 menit dengan api kecil.

Penelitian ini dilaksanakan di Laboratorium Pendidikan Teknologi Pertanian Fakultas Teknik Universitas Negeri Makassar dan hasil produk dianalisis di Balai Besar Industri Perkebunan Makassar dan Labratorium Produktifitas dan Kualitas Perairan Fakultas IImu Kelautan dan Perikanan Universitas Hasanuddin, jangka waktu penelitian mulai dari persiapan sampai dengan pengamatan membutuhkan waktu kurang lebih tiga bulan, sejak diterbitkannya surat izin penelitian.

\section{HASIL DAN PEMBAHASAN}

\section{Kadar Klorida $\left(\mathrm{Cl}^{-}\right)$}

Klorida adalah ion yang terbentuk sewaktu unsur klor mendapatkan satu elektron untuk membentuk suatu anion (ion bermuatan negatif) $\mathrm{Cl}^{-}$. Garam dari asam klorida $\mathrm{HCl}$ mengandung ion klorida; contohnya adalah garam meja, yang adalah natrium klorida dengan formula kimia $\mathrm{NaCl}$. Dalam air, senyawa ini terpecah menjadi ion $\mathrm{Na}^{+}$dan $\mathrm{Cl}^{-}$. 


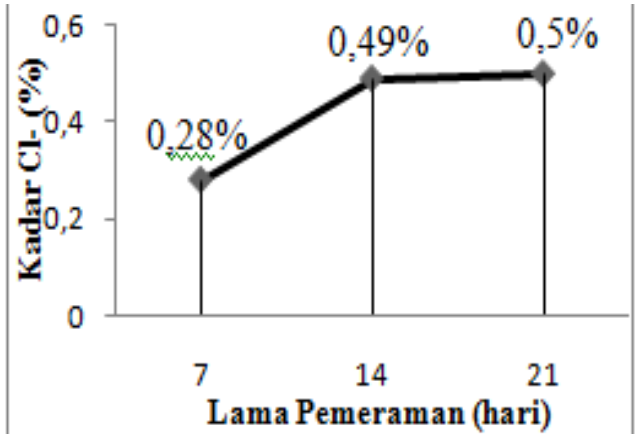

Gambar 4.1. Kadar Klorida Telur Asin Menggunakan Media Abu Sabut Kelapa.

Dari hasil uji yang telah dilakukan, Kadar klorida semakin meningkat dengan semakin lama dilakukan pemeraman. Hal ini disebabkan karena kandungan garam dalam media abu sabut kelapa mengion masuk kedalam telur yang menyebabkan telur menjadi asin dan lama pemeraman berpengaruh terhadap konsentrasi kadar klorida.

Rata-rata kadar klorida pada setiap perlakuan berbeda-beda dan semakin lama telur diperamkan kadar klorida semakin meningkat. Lamanya waktu pemeraman sangat berpengaruh terhadap kadar klorida telur asin. Hasil uji lanjut memperlihatkan bahwa perlakuan lama pemeraman 21 hari merupakan perlakuan yang terbaik untuk pengunaan media abu sabut kelapa adapun perlakuan kontrol yang menggunakan media abu gosok dari sekam padi dan garam dapur memiliki kadar klorida yang lebih tinggi. Hal ini menunjukkan bahwa media yang digunakan sangat berpengaruh terhadap jumlah kadar klorida yang berpenetrasi kedalam telur asin serta semakin lama telur diperamkan hasil telur asin semakin baik karena kadar klorida yang semakin meningkat serta, sehingga proses pembusukkan oleh enzim dan bakteri pembusuk dapat dicegah.

Perbedaan kandungan kadar klorida perlakuan control dan perlakuan menggunakan abu sabut kelapa sangat berbeda nyata, diketahui bahwa perlakuan kontrol kandungan kadar klorida lebih tinggi dari kandungan kadar klorida dengan menggunakan media abu sabut kelapa, hal ini disebabkan kandungan kadar klor dalam garam kasar lebih besar dari kandungan klor yang terdapat pada media abu sabut kelapa.

Hasil uji klorida yang menggunakan media abu sabut kelapa dengan lama pemeraman 7 hari dan 14 hari memperlihatkan kadar klorida meningkat secara signifikan hal ini disebabkan oleh beberapa faktor, salah satunya adalah jumlah klorida yang terdapat pada abu sabut mempengaruhi jumlah penetrasi kadar klorida yang masuk kedalam telur, dimana pada proses ionisasi klor pada minggu pertama dan kedua merupakan tahap penetrasi yang paling optimal. Lama pemeraman 14 hari dan 21 hari memperlihatkan kandungan kadar klorida terlihat tidak menunjukkan perubahan signifikan hal ini dikarenakan jumlah klor yang ada pada media abu sabut kelapa mulai menipis dan berkurang dikarenakan telah terpakai pada proses penetrasi minggu pertama dan minggu kedua.

Hal ini sesuai dengan pernyataan Widyani (2008) dalam Riana (2015) yang menyatakan bahwa garam akan terionisasi dan menarik sejumlah molekul air, peristiwa ini disebut hidrasi ion. jika konsentrasi garam makin besar, maka makin banyak ion hidrat dan molekul air terjerat, sehingga menyebabkan Aw bahan pangan menurun. Aktivitas garam dalam menarik air ini erat kaitannya dengan peristiwa plasmolysis, dimana air akan bergerak dari konsentrasi garam rendah ke konsentrasi garam tinggi karena adanya perbedaan tekanan osmosis. Garam dengan konsentrasi rendah berfungsi sebagai pembentuk cita 
rasa, sedangkan dalam konsentrasi tinggi mampu berperan sebagai pengawet.

Fungsi ganda dari garam (klorida) sebagai pengawet karena sifat osmotiknya yang tinggi, kemampuan mengikat air, dan mengakibatkan denaturasi protein. Garam (klorida) dalam larutan akan terionisasi menjadi ion Cl-ini bersifat toksik bagi mikroba (Soeparno, 1994 dalam Asih et al, 2011).

\section{Pernyataan} serupa juga dikemukakan oleh Hari (2004) dalam Asih et al. (2011) menyatakan berkurangnya air pada telur asin menyebabkan telur menjadi lebih awet, garam (klorida) akan masuk kedalam telur dengan cara merembes ke pori-pori kulit, menuju bagian putih, dan akhirnya ke kuning telur. Garam (klorida) akan diubah menjadi ion chlor $\left(\mathrm{Cl}^{-}\right)$.

Ion chlor inilah yang berfungsi sebagai bahan pengawet, dengan menghambat mikroba pada telur. Semakin lama dibungkus dengan adonan, semakin garam (klorida) merembes kedalamnya, sehingga telur menjadi awet dan asin.

\section{Kadar Protein}

Protein merupakan komponen terbesar yang terdapat di dalamtubuh setelah air. Protein tersebar diseluruh bagian tubuh manusia.Senyawa ini terbentuk dari unsur-unsur organik yang hampir sama dengan karbohidrat dan lemak yaitu karbon $(C)$, hidrogen $(H)$, dan oksigen (O), tetapi ditambah dengan unsur nitrogen $(\mathrm{N})$. Satu satunya sumber nitrogen bagi tubuh berasal dari protein.

Sumber protein yang lengkap adalah protein yang mengandung kesembilan asam amino esensial dalam jumlah cukup. Protein yang terdapat pada hewan seperti daging, ikan, hasil ternak, telur dan lainnya merupakan contoh protein yang lengkap. Tanaman pangan terutama biji-bijian dan serealia sering kekurangan satu atau lebiuh asam amino esensial tapi bisa menjadi lengkap bila digabungkan dengan sumber protein lainnya. Dengan mengkonsumsi makanan dalam jumlah cukup selama kandungan kalori pada makanan tersebut cukup tinggi (Wirakusumah, 2002).

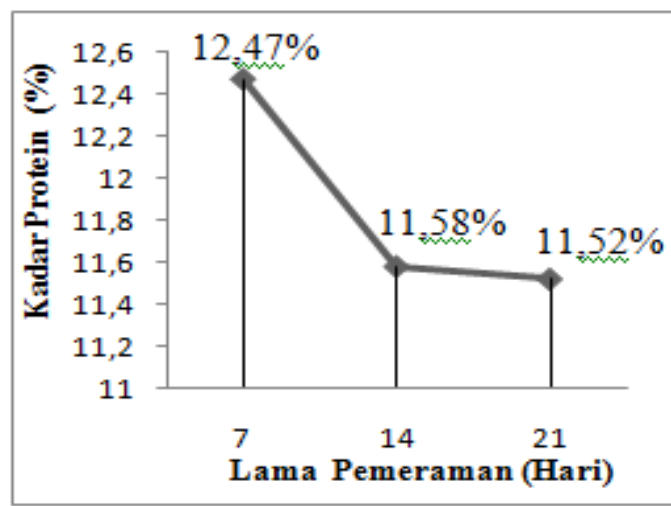

Gambar 4.3. Kadar Protein Telur Asin

Berdasarkan hasil uji kadar protein lama pemeraman 7 hari menggunakan abu sabut kelapa merupakan perlakuan yang terbaik dengan dengan kadar klorida tertinggi, diikuti perlakuan kontrol menggunakan media abu gosok dari sekam padi dan garam dapur, perlakuan 14 hari, dan perlakuan lama pemeraman 21 hari menggunakan media abu sabut kelapa merupakan perlakuan dengan kadar protein terendah.

Kualitas telur asin kontrol menggunakan abu gosok dari sekam padi dengan dan garam kasar dengan perbandingan 1:1 yang dilakukan masyarakat secara umum dengan masa pemeraman 7 hari, memiliki kadar protein lebih rendah dari perlakuan menggunakan media abu sabut kelapa dengan waktu pemeraman 7 hari, hal ini dikarenakan denaturasi protein pada perlakuan kontrol menggunakan abu gosok dan garam lebih tinggi dari perlakuan menggunakan media abu sabut 
kelapa, dimana kandungan kadar klor pada media garam dapur lebih besar dari kandungan klor pada media abu sabut kelapa yang memungkinkan denaturasi terhadap telur asin lebih besar.

Penambahan garam secara berlebihan pada proses pengawetan telur dapat menyebabkan terjadinya denaturasi. Denaturasi terjadi karena adanya gangguan pada struktur sekunder dan tersier protein.Pada struktur protein tersier terdapat empat jenis interaksi yang membentuk ikatan pada rantai samping seperti; ikatan hidrogen, jembatan garam, ikatan disulfida dan interaksi hidrofobik non polar, yang kemungkinan mengalami gangguan. Denaturasi yang umum ditemui adalah proses presipitasi dan koagulasi protein.

Hasil dari perlakuan pada minggu pertama keperlakuan minggu kedua memiliki kadar protein menurun secara signifikan hal ini dikarenakan peningkatan penetrasi klorida yang masuk kedalam telur juga terlihat sangat signifikan hal ini disebabkan oleh beberapa faktor, salah satunya adalah jumlah klorida yang terdapat pada abu sabut kelapa yang mempengaruhi jumlah penetrasi kadar klorida yang masuk kedalam telur, dimana pada proses ionsisi klor pada minggu pertama dan kedua merupakan tahap penetrasi klor yang paling optimal.

Lama pemeraman 14 hari dan 21 hari memperlihatkan kandungan kadar protein terlihat tidak menunjukkan perubahan signifikan hal ini dikarenakan jumlah klor yang berpenetrasi kedalam isi telur lebih sedikit dikarenakan telah terpakai pada proses penetrasi minggu pertama keminggu kedua.

Pernyataan diatas sesuai dengan hasil penelitian yang dilakukan oleh Gumay (2009), menunjukkan proses pengasinan menurunkan secara nyata kadar protein telur asin dibandingkan dalam telur segar. Hal tersebut dapat dikarenakan penambahan garam mengurangi daya larut protein, sehingga ketika diuji terlihat nilainya berkurang akibat proteinnya terpisah menjadi endapan karena pada pengujian dengan cara Kjeldahl sampelnya dilarutkan.

Hal ini sependapat dengan Hasil penelitian yang dilakukan oleh Safrullah Amir et al. (2014) dimana proses pengasinan menurunkan secara nyata kadar protein telur asin dibandingkan dalam telur segar. Hal tersebut dapat dikarenakan pada proses pengolahan telur asin dengan penambahan garam dan lama periode pemeraman. semakin lama telur asin disimpan, maka tingkat denaturasi juga semakin tinggi.

Lama waktu pemeraman juga sangat berpengaruh terhadap kadar protein telur asin. Hal ini menjelaskan bahwa semakin lama telur diperamkan maka semakin menurun kadar protein yang dihasilkan pada masing-masing perlakuan hal ini disebabkan oleh tingginya kadar klorida yang berpenetrasi kedalam telur mengakibatkan kadar protein menurun.

Pemasakan telur asin juga merupakan salah satu penyebab denaturasi protein, dimana semakin tinggi suhu saat pemasakan maka akan terjadi denaturasi protein yang mengakibatkan perubahan struktur protein oleh suhu air yang berbeda. Menurut Zulfikar (2008).

denaturasi protein merupakan suatu keadaan dimana protein mengalami perubahan atau perusakan struktur sekunder, tersier dan kuartenernya. Sedangkan faktor yang dapat menyebabkan terjadinya denaturasi protein diantaranya pemanasan, suasana asam atau basa yang ekstrim, kation logam berat dan penambahan garam jenuh. Hal ini sejalan dengan hasil penelitian Hidayati dan Mardiono (2009) 
semakin lama pengasinan kadar protein pada puth telur asin mengalami penurunan.

\section{Uji Hedonik (kesukaan)}

Uji hedonik dilakukan untuk mengetahui tingkat kesukaan panelis terhadap produk telur asin yang dihasilkan. Analisis secara subyektif dilakukan dengan bantuan panca indera manusia untuk menilai daya terima suatu bahan, dapat juga untuk menilai karakteristik mutu, yang dilakukan dengan tujuan untuk mengetahui sifat-sifat fisik suatu bahan. Hasil pengamatan uji hedonik aroma, warna, tekstur dan rasa yang telah dilakukan dapat dilihat pada Gambar 4.6 berikut.

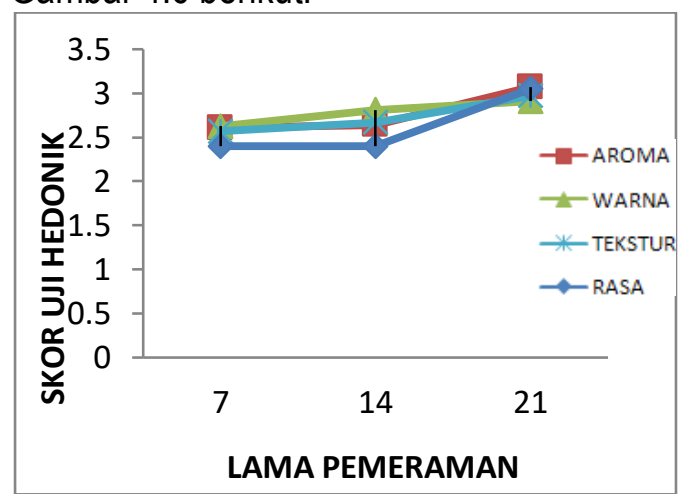

Gambar 4.6. Hasil Uji Hedonik Aroma, Warna, Tekstur dan rasa Telur Asin.

\section{a. Aroma}

Aroma adalah bau yang dapat diamati dengan indra pembau. Pengujian bau atau aroma adalah salah satu pengujian yang penting karena dapat memberikan hasil penilaian terhadap daya terima produk (Kartika et al, 1988 dan Setyaningsih et al, 2010). Aroma dapat digunakan sebagai indikator terjadinya kerusakan pada produk pangan. Telur asin yang sudah tidak layak dikonsumsi akan berbau sangat menyengat/busuk.

Aroma memiliki fungsi yang penting dalam produk pangan, karena sebelummengkonsumsi biasanya terlebih dahulu aroma makanan tercium oleh indra hidung, apabila aroma pada produk terlalu menyengat atau terkesan hambar akan membuat konsumen tidak tertarik mengkonsumsi.

Penilaian tingkat kesukaan telur asin dari aroma pada telur asin berkisar 2,61 sampai 2,64 yaitu suka pada perlakuan masing-masing 7, 14 hari. Pada perlakuan 21 hari tingkat kesukaan panelis memiliki nilai skor 3,07 walaupun ada peningkatan skor pada perlakuan 21 hari tetapi masih dalam kategori di sukai. Dengan semakin lama telur diperamkan maka semakin tingkat kesukaan meningkat, karena media abu sabut kelapa dapat menghilangkan bau amis pada telur.

\section{b. Warna}

Selain untuk selera, warna dalam suatu produk khususnya produk makanan memegang peranan penting dalam daya terima konsumen. Apabila suatu produk memiliki warna yang menarik dapat meningkatkan selera konsumen untuk mencoba makanan tersebut. Setyaningsih (2010) menambahkan bahwa warna menjadi atribut kualitas yangpaling penting, walaupun suatu produk pangan bernilai gizi tinggi, rasa enak dan teksturbaik, namun apabila warna yang ditampilkan kurang menarik akan menyebabkan produkpangan kurang diminati oleh konsumen. Pengujian dengan indra penglihat masih sangat menentukan dalam pengujian sensoris warna pada produk pangan (Putri, 2011).

Penilaian tingkat kesukaan warna terhadap produk telur asin menunjukkan bahwa perlakuan lama pemeraman 7 dan 14 hari berdasarkan hasil uji hedonic warna memiliki skor masing-masing yaitu 2,91dan 2,8 artinya dalam kriteria suka, sedangkan untuk penilaian tingkat 
kesukaan warna pada perlakuan lama pemeraman 21 hari memiliki skor nilai 2,63 yang artinya suka. Hasil perhitungan sidik ragam uji hedonik warna telur asin diperoleh hasil lama pemeraman pada setiap perlakuan tidak berpengaruh nyata terhadap kesukaan konsumen. Hasil pengujian hedonik terhadap warna kuning telur menunujukkan bahwa semakin lama pemeraman dengan abu sabut kelapa maka warna dari kuning telur pada bagian pinggir agak keabu-abuan.

Warna kuning telur dipengaruhi oleh kepekatan bahan, dimana kepekatan bahan dipengaruhi oleh kadar garam $\mathrm{KCL}$ yang terdapat dalam abu sabut kelapa serta lamanya waktu pemeraman berpengaruh terhadap warna telur. Semakin lama pemerman maka menyebabkan semakin banyak yang ditarik oleh ion hidrat, sehingga kondisi bahan semakin pekat, termasuk zat warna yang teradapat dalam bahan.

Warna putih telur yang dihasilkan dari masing-masing perlakuan tidak jauh berbeda. Putih telur dengan waktu pemeraman yang singkat berwarna putih, sedangkan putih telur dengan perendaman yang lama berwarna semakin pekat. Hal ini dapat disebabkan karena adanya kandungan kalium dalam abu sabut kelapa. Kandungan kalium dalam abu sabut kelapa dapat menyebabkan perubahan warna pada putih telur. Jadi semakin lama waktu pemeraman semakin tua/pekat warna putih telur. Walaupun dalam hasil penelitian uji hedonic warna telur asin yang telah dilakukan sedikit berbeda namun masih dalam taraf yang masih diterima oleh konsumen.

\section{c. Rasa}

Rasa merupakan salah satu faktor penting dalam produk pangan. Rasa telur asin umumnya terasa asin, sesuai dengan tingkat pemberian garam atau media dalam pembuatan telur asindan juga lama pemeraman.

Berdasarkan hasil pengamatan uji hedonik nilai rasa telur asin berkisar masing-masing antara $2,40 \%$ pada perlakuan lama pemeraman 7 dan 14 hari berdasarkan hasil uji hedonik memiliki skor 2 dengan kriteria agak suka, dan pada lama pemeraman 21 hari berdasarkan hasil uji hedonik rasa memiliki skor 2,9 atau 3 yang berarti suka.

Perhitungan sidik ragam pada rasa telur asin diperoleh hasil lama pemeraman 7 dan 14 hari tidak berpengaruh terhadap kesukaan konsumen terhadap rasa telur asin sedangkan pada perlakuan 21 hari berpengaruh terhadap kesukaan konsumen.

Dapat dilihat pada uji hedonic rasa telur asin yang diperam lebih lama mempunyai rasa paling asin daripada telur asin yang diperam dengan waktu yang lebih singkat. $\mathrm{Hal}$ tersebut dikarenakan rasa asin pada telur asin yang dibuat dipengaruhi oleh kadar garam yang terdapat dalam abu sabut kelapa dan lama waktu pemeraman dalam abu.

Abu sabut kelapa mengandung garam $\mathrm{MgCl}$ dan $\mathrm{KCl}$ yang menyebabkan telur itik menjadi asin. Semakin lama waktu pemeraman maka semakin banyak pula kandungan garam $\mathrm{MgCl}^{2}$ yang meresap ke dalam telur sehingga rasa telur menjadi asin.Hasil uji lanjut memperlihatkan bahwa perlakuan dari masing-masing waktu berbeda nyata atau ada pengaruh nilai statistic terhadap penelitian. Tingkat kesukaan panelis semakin meningkat dengan semakin lama produk telur asin diperamkan. 


\section{d. Tekstur}

Hasil uji hedonik tekstur pada telur asin berkisar antara 2,57 sampai dengan 2,97. Perlakuan lama pemeraman 7 dan 14 hari memiliki nilai rata-rata masingmasing yaitu 2,57 dan 2,65 artinya (suka), Sedangkan pada perlakuan lama pemeraman 21 hari berdasarkan hasil uji hedonic memiliki skor 2,97 atau 3 yang masih dalam taraf (suka). Factor yang mempengaruhi tekstur telur asin adalah lama waktu pemeraman, karena semakin lama waktu pemeraman maka telur semakin kenyal. hal ini terjadi karena waktu pemeraman yang panjang menarik molekul air dari telur, sehingga telur menjadi lebih kenyal agak keras. Tekstur kenyal pada putih telur disebabkan karena putih telur mengalami koagulasi pada saat proses pemanasan. Koagulasi terjadi pada suhu $60-70^{\circ} \mathrm{C}$ (Siti Zulaekah, 2002).

\section{KESIMPULAN}

\section{Berdasarkan hasil pembahasan dalam penelitian ini, maka dapat disimpulkan sebagai berikut:}

1. Waktu terbaik proses pembuatan telur asin dengan media abu sabut kelapa selama 21 hari.

2. Hasil kadar klorida telur asin tertinggi pada perlakuan 21 hari dan kadar klorida terendah pada perlakuan 7 hari, sedangkan hasil kadar protein tertinggi yaitu pada perlakuan 7 hari dan kadar protein terendah pada perlakuan 21 hari.

3. Hasil uji hedonik rasa dengan lama pemeraman 21 hari memberikan pengaruh berbeda nyata dan merupakan perlakuan paling disukai, sedangkan hasil uji kesukaan warna, aroma dan tekstur dengan perlakuan lama pemeraman 7, 14, 21 hari memiliki kriteria yang relative sama.

\section{DAFTAR PUSTAKA}

Asih, Wijayanti Sugiarto. 2011. Pengaruh Kionsentrasi Keragenan Dan Gula Pasir Terhadap Sifat Fisikokimia Dan Organoleptik Jelly Drink AlangAlang (Imperata Clindrica (L) $P$. Beauv). Undergraduate Twais, Widya Mandala Catholic University Surabaya.

Armenia Eka Putriana, Saifuddin Sirajuddin, Ulfa Najamuddin, 2014. Pengaruh Konsentrasi Garam Dan Lama Penyimpanan Terhadap Kandungan Mikroba Telur Asin. Program Studi IImu Gizi Fakultas Kesehatan Kota Makassar Universitas Hasanuddin.

Gumay, T.R. 2009. Kandungan Beta Karoten Dan Nilai Gizi Telur Asin Dari Itik Yang Mendapatkan Limbah Udang. Program Studi Teknologi Hasil Ternak. Fakultas Peternakan. Institut Pertanian Bogor.

Hidayati, N dan Mardiono. 2009. Pengaruh waktu pengasinan terhadap kadar protein putih telur. Jurnal Biomedika. 2 (1) : 81-86.

Kartika, B., Hastuti, P dan Suprapto, W. 1988. Pedoman Uji Inderawi Bahan Pangan. Yogyakarta.

Putri, I. S. I. 2011. Pengaruh Penambahan Ekstrak Jahe (Zingiber Officinale Roscoe) Terhadap Aktifitas Antioksidan, Total Fenol Dan Karakteristik Sensoris Pada Telur Asin. Skripsi Penelitian. Mahasiswa Fakultas Teknologi Hasil Pertanian. 
Universitas Sebelas Maret

Surakarta. Surakarta.

Riana. 2015. Kandungan formalin dan kadar garam pada ikan sunu asin dari pasar tradisional Makassar. Sul-Sel. Fakultas Kedokteran. Unhas.

Safrullah Amir, Saifuddin Sirajuddin, Nurhaedar Jafar. 2014. Pengaruh Konsentrasi Garam dan Lama Penyimpanan TerhadapKandungan Protein dan Kadar Garam Telur Asin. Unhas.

Setyaningsih, Apriantono, Maya, S. 2010. Analisis Sensori untuk industri pangan dan agro. Bogor

Siti Zulaekah. 2002. IImu Bahan Makanan 1. Fakultas IImu Kesehatan. Universitas Muhammadiya Surakarta.

Wahyudi Eka Putra, Nurhaedar Jafar Dan Saifuddin Sirajuddin. 2014. Pengaruh Konsentrasi Garam Dan Lama Penyimpanan Terhadap Daya Terima Produk Telur Asin Rebus Pada Mahasiswa IImu Gizi FKM Universitas Hasanuddin. Program Studi IImu Gizi Fakultas Kesehatan Kota Makassar Universitas Hasanuddin.

Wirakusumah, S., Emma. 2002. Buah Dan Sayur Untuk Terapi. Yogyakarta: Swadaya.

Zulfikar. 2008. Sifat fisik dan organoleptik telur ayam ras hasil perendaman dalam campurn larutan garam dengan ekstrak jahe yang berbeda. Institut Pertanian Bogor. 